\title{
Opinions of Social Studies Teacher Candidates Prepared for KPSS Regarding the Effect of the Pandemic Period on Their Course Studies
}

\author{
Mehmet ORAN $^{1}$ \\ ${ }^{1}$ Social Studies Education Department, Faculty of Education, Usak University, Turkey \\ Correspondence: Mehmet ORAN, Social Studies Education Department, Faculty of Education, Usak University, \\ Turkey. E-mail: mehmet.oran@usak.edu.tr
}

Received: January 1, 2021

Accepted: March 2, $2021 \quad$ Online Published: May 7, 2021

doi:10.5539/ies.v14n6p12

URL: https://doi.org/10.5539/ies.v14n6p12

\begin{abstract}
This study aims to reveal the opinions of social studies teacher candidates who are prepared for KPSS on the effects of the pandemic period on their studies. KPSS: It is the shortening of the Public Personnel Selection Exam. These exams determine people to work in public institutions and organizations in Turkey. The phenomenology model, one of the qualitative research techniques, was used in the study. The study group of the research consists of 34 teacher candidates $($ male $=19$, female $=15)$ graduated from Usak University, Department of Social Studies. In the collection of data in the research, firstly review of literature about the subject was done, and then a semi-structured interview form was used to apply to social studies teacher candidates. Some questions are standardized, some questions are prepared open-ended. In this type of interview, it is possible to obtain in-depth information. The data collected within the scope of the research were transferred to a word file in computermediated and subjected to content analysis. At the end of the research, the most frequently applied sources of candidate teachers preparing for KPSS during the pandemic period is that; videos, books, online lessons, articles and lesson notes. The teacher candidates stated that their families' attitudes towards them were generally positive during the pandemic period. The advantages of the pandemic period was revealed that candidate teachers studied more than usual, the disadvantages of the pandemic periodwas that there was no activity, anxiety and stress increased, and the fear of getting sick came out. In addition, it was emphasized in the study that preparing for KPSS during the pandemic period is more difficult than preparing for it in the normal period.
\end{abstract}

Keywords: KPSS, social studies, pandemic

\section{Introduction}

Throughout history, almost every society has suffered heavy losses in epidemics such as plague, cholera, influenza and smallpox, and the inability to prevent this epidemic at that time caused great fear and anxiety among people (Karatas, 2007). These epidemic diseases, which affect the world from time to time, have increased especially in recent years and have been on the world press very often. The epidemic diseases that emerged as SARS in 2002, Bird Flu in 2005, Swine Flu in 2009, EBOLA in 2014, emerged with the name of COVID-19 in late 2019 and deeply affected the whole world (Ornek Buken, 2020).

The new disease that emerged in Wuhan, Hubei Province of China in December 2019 was named as COVID-19 by the World Health Organization on February 11, 2020. The same health institution declared the COVID-19 outbreak as a pandemic disease on March 12, 2020, taking into account the spread and severity of the new disease (Arslan \& Karagul, 2020).

COVID-19 virus is an enveloped RNA virus which is from the corona family such as SARS-COV and MERS-COV and causes severe respiratory failure, which is thought to be transmitted from animals to humans. RNA viruses are pathogens that usually emerge in wild animals and infect humans, with a high mutational ability and an epidemic rate (Carrasco-Hernandez et al., 2017). The most common symptoms of COVID-19 are fever, shortness of breath, and cough. It has been observed that the disease is usually transmitted from person to person through droplets formed by cough, and with the progression of the disease, it causes severe acute respiratory failure, organ failure, pneumonia, and even death (TUBA, 2020).

SARS-COV is an epidemic disease that emerged in China in 2002 and spread to the world in 2002-2003 and killed 774 people, but MERS-COV is an epidemic disease that emerged in Saudi Arabia in 2012 and has been seen in 
many countries until today (Ozlu \& Oztas, 2020).

Epidemics are diseases that are seen in multiple countries or continents around the world and have a wide range of effects, and these diseases are generally called pandemic diseases. The World Health Organization has determined 3 criteria for a disease to be called as a pandemic. These are: it must be a new virus or a mutated factor, it must be easily passed on to humans, must be constantly and easily infectious to humans (TUBA, 2020).

Pandemics are disasters that put societies in serious trouble. Such situations bring along many problems such as transportation, culture, food, tourism, economy, health, education... Education is one of the most important issues as it shapes the future of societies. Because education is undoubtedly a very important factor in the development of many sectors such as health, tourism, food and economy.

With the COVID-19 epidemic, societies have realized the importance of education and have attempted to improve to the infrastructure of education systems by giving importance (Tezekici, 2020). Turkey has taken measures in many areas as soon as COVID- 19 epidemic arise. The field of education has become one of these areas. Firstly Turkey had a break to education and then began to distance education (Kurnaz \& Sercemeli, 2020). While Turkey was applying to distance education model, It has also benefited greatly from the technology to ensure equality of opportunity for students (Kocoglu et al., 2020).

When we look at the works revealed about the pandemic period (Covid-19 outbreak), it is seen that these are generally in the field of health. Business, sociology and education follow the field of health. It is seen that the number of studies on the pandemic issue in the field of education has recently increased. In this study, the effects of the pandemic process on education and especially in the field of social studies are discussed. In this context, the study aims to reveal the opinions of social studies teacher candidates prepared for KPSS regarding the effect of the pandemic period on their course studies. In addition, the study aims to shed light on other studies planned in this field.

\section{Method}

The phenomenology model, one of the qualitative research techniques, was used in the study. In studies where the phenomenological model is used, issues that we are aware of but do not have detailed information are dealt with scientifically (Yıldırım \& Simsek, 2008).

\subsection{Working Group}

The study group of the research consists of 34 teacher candidates who graduated from Usak University Social Studies Teaching Department and (Male $=19$, Female $=15)$ who were prepared for KPPS. Participants included in the study were shortened and coded as "P". While forming the study group, the accessibility to the teacher candidates and the answers that the teacher candidates could give to the questions in the interview form were taken into consideration. In this study in which the easily accessible and convenient sampling method is used among purposeful sampling methods, it is in the foreground to choose the easy one because it is in question to save effort, money and time (Baltac1, 2018). In addition, in the purposeful sampling method, it is a matter of selecting information-rich situations and conducting in-depth and detailed research (Buyukozturk, Kılıc Cakmak, Akgun, Karadeniz, \& Demirel, 2008).

\subsection{Data Collection and Analysis}

In the first stage of collecting the data, the literature on the subject was reviewed. As it is known, literature review is the process of collecting data using different documents and sources in order to eliminate the deficiencies in the literature related to the subject determined (Timmins \& McCabe, 2005). Then, a semi-structured interview form was used to be applied to social studies teacher candidates. The semi-structured interview form was confirmed by 3 expert academicians in the field of social studies education. The main purpose of seeking expert opinion is to increase the reliability and validity of the research. The data collected within the scope of the research were transferred to Word files in computer environment and subjected to content analysis. In content analysis, it is the matter of examining the data in detail and clarifying it. (Tedmem, Palanc1, Kandemir, \& Dundar, 2014). In addition, in calculating the reliability of the study, the reliability formula of Miles and Huberman (1994) was used [Percentage of Agreement = Agreement $/($ Agreement + Disagreement) x 100] and the reliability of the study was calculated as $92 \%$.

The answers given by the social studies teacher candidates participating in the study to the questions in the semi-structured interview form were collected in 62 codes in the first stage, then this number was reduced to 25 by associating these codes with each other. Some of these codes are: Video, book, online lesson, article, lesson notes, more KPSS study, preventing loss of time, inability to do activities, not being able to socialize, anxiety, stress, boredom, unwillingness, inability to focus, not being motivated, fear of getting sick, etc. 


\section{Results}

In this section, first of all, personal information of the teacher candidates who participated in the study was given. Then, the answers given by the participants to the research questions were included. The personal information of the teacher candidates participating in the study is given in Table 1.

Table 1. The personal information of teacher candidates, graduated from usak university social studies teaching department, who participated in the study

\begin{tabular}{|c|c|c|c|}
\hline Participant & Gender & Hometown & Date of Graduation \\
\hline 1 & Male & Izmir & 2019 \\
\hline 2 & Male & Sanliurfa & 2019 \\
\hline 3 & Female & Usak & 2019 \\
\hline 4 & Female & Balıkesir & 2019 \\
\hline 5 & Female & Adana & 2019 \\
\hline 6 & Male & Usak & 2019 \\
\hline 7 & Male & Afyonkarahisar & 2019 \\
\hline 8 & Female & Afyonkarahisar & 2018 \\
\hline 9 & Male & Manisa & 2019 \\
\hline 10 & Male & Usak & 2019 \\
\hline 11 & Male & Denizli & 2019 \\
\hline 12 & Female & Manisa & 2019 \\
\hline 13 & Female & Sanliurfa & 2018 \\
\hline 14 & Female & Manisa & 2018 \\
\hline 15 & Female & Usak & 2019 \\
\hline 16 & Female & Usak & 2019 \\
\hline 17 & Male & Usak & 2018 \\
\hline 18 & Male & Afyonkarahisar & 2019 \\
\hline 19 & Female & Kutahya & 2020 \\
\hline 20 & Female & Mugla & 2020 \\
\hline 21 & Male & Usak & 2019 \\
\hline 22 & Female & Ankara & 2016 \\
\hline 23 & Male & Usak & 2016 \\
\hline 24 & Male & Usak & 2019 \\
\hline 25 & Female & Usak & 2019 \\
\hline 26 & Male & Usak & 2018 \\
\hline 27 & Male & Manisa & 2017 \\
\hline 28 & Male & Usak & 2017 \\
\hline 29 & Female & Kutahya & 2016 \\
\hline 30 & Male & Usak & 2017 \\
\hline 31 & Male & Usak & 2016 \\
\hline 32 & Female & Manisa & 2016 \\
\hline 33 & Male & Usak & 2017 \\
\hline 34 & Male & Usak & 2017 \\
\hline
\end{tabular}




\subsection{Results Regarding the Answers Given by the Participants to the Research Questions}

Table 2. Findings regarding the opinions of the social studies teacher candidates participating in the study about the sources that they most appeal to while preparing for KPSS during the pandemic period

\begin{tabular}{|c|c|c|}
\hline Codes & Participant & $\mathrm{f}$ \\
\hline Video & $\begin{array}{l}1,3,4,5,6,7,8,10,12,13,14,15,16,17,18,19,20,21,22,23,24,25,26,27,29,30,31, \\
32,33\end{array}$ & 29 \\
\hline $\begin{array}{l}\text { Book-including subject and question } \\
\text { bank }\end{array}$ & $1,4,5,6,7,8,9,10,12,13,14,15,16,17,18,19,20,21,22,23,24,25,26,27,28,29,32$ & 27 \\
\hline Online Lesson & $2,9,10,11,19,21,22,25,26,28,30,32,34$ & 13 \\
\hline Article & $6,9,11,15$ & 4 \\
\hline Lesson Notes & 3,5 & 2 \\
\hline
\end{tabular}

To the question "What are the resources you appeal most while preparing for KPSS during the pandemic process?", the pre-service teachers who graduated from Usak University, Department of Social Studies Teaching, prepared for KPSS and participated in the study stated that they used more than one source together in this process. When the answers given by the teacher candidates participating in the study regarding this question are coded, respectively: video $(f=29)$, book $(f=27)$, online lesson $(f=13)$, article $(f=4)$ and lesson notes $(f=2)$ are revealed.

Some direct quotations regarding the video responses of the teacher candidates participating in the study are as follows:

P.12 "The resources I applied the most during the pandemic process were the videos and question banks I solved as an supplementary resource for lessons."

P.18 "While preparing for KPSS during the pandemic period, I generally benefited from video and KPSS-related books."

P.19 "First of all, I was able to access online resources in a limited way because I had problems with the internet. In the beginning, I benefited from most and contributed the most to me were the online lesson videos. Also I benefited from KPSS test books."

P.27 "While I was working KPSS, I mostly watched videos over the internet, because working on a computer was the most hygienic method during the pandemic period. I also benefited from my books about KPSS."

P.31 "During the pandemic period, I generally watched lesson videos about KPSS."

P.33 "I prepared for KPSS by watching lesson videos."

Some direct quotations regarding the book responses of the teacher candidates participating in the study as are follows:

P.10 "As I went to the private teaching institution, the lessons, the test and books distributed by the institution were my priority. During the pandemic period, the lessons continued on online site opened by the private teaching institution. In addition, I supported myself on the subjects I found incomplete with online courses over the internet."

P.13 "During the pandemic period, while preparing for KPSS, the sources I used the most were books and videos."

P.14 "I mostly benefited from books and videos while preparing for KPSS during the pandemic period."

P.24 "I have benefited from books and question banks for KPSS. I also received support from the distance education package of our field teacher for my field course."

P.25 "I made use of the books of publications for KPSS. I listened to geography and history lessons on the internet. I attended online lessons of some professors for field lessons. I solved the questions of the past years."

P.29 "I used field books for KPSS and videos from the internet as a source."

Some direct quotations regarding online lesson responses of pre-service teachers participating in the study are as follows:

P.2 "While I was preparing for KPSS during the pandemic period, the most used resource that I used was online lessons."

P.21 "During the pandemic period, I applied mostly to online lessons. I studied my lessons from online videos and 
KPSS sets."

P.22 "Private teaching institution did online lessons during the pandemic period and I attended them. I followed live broadcasts and video lessons of popular teachers on social media. Again, I used the books of the same popular teachers."

P.34 "I prepared for KPSS by following online lessons."

Some direct quotations regarding the article responses of the preservice teachers who participated in the study are as follows:

P.6 "I have benefited from videos, academic articles and books while preparing for KPSS during the pandemic process."

P.9 "The books, online lessons and articles I have purchased are the most common sources I appeal to during the pandemic period."

P.15 "During the pandemic period, the sources I used most were test books, books, articles, and question-solution videos while preparing for KPSS."

Some direct quotations regarding the answers to the lesson notes of the teacher candidates participating in the study are as follows:

P.3 "During the pandemic period, while preparing for KPSS, the sources I applied the most were videos, lesson notes and question banks."

P.5 "During the pandemic period, while I was preparing for KPSS, I studied from the video lesson recordings that I accessed on the internet by taking notes and I solved questions from the trial booklets."

Table 3. Findings regarding the opinions of social studies teacher candidates participating in the study about their families' attitudes towards them while they were preparing for KPSS during the pandemic process

\begin{tabular}{llc}
\hline Cods & Participants & $\mathrm{f}$ \\
\hline Positive & $2,3,4,5,6,7,8,9,10,11,12,16,17,18,19,20,21,22,24,25,28,29,31,33,34$ & 25 \\
Negative & $1,14,15,23,27$ & 5 \\
There was no change & $13,26,30,32$ & 4 \\
\hline
\end{tabular}

The answer to the question "How was your family's attitude towards you while you were preparing for KPSS during the pandemic period?" is that the candidate teachers participating in the study stated 3 different opinions: positive ( $\mathrm{f}=25)$, negative $(\mathrm{f}=5)$ and no change $(\mathrm{f}=4)$.

Candidates teachers participating in the study stated that their families were supportive, helpful, motivating, understanding and tolerant under the name of positive opinion code. Some direct quotes about positive views are as follows:

P.2 "My family's attitude was more positive in this period. They were acting in a motivating way."

P.9 "My family has always been with me. On the days when I was desperate, they gave morale and motivation. During the pandemic period, my biggest supporter was my family."

P.10 "My family has always been with me financially and morally. They were the driving force when I got tired of studying. In any failure, they supported me by saying that they would be with me again."

P.20 "My family has always been supporting me. They provided the necessary facilities for my study as much as they could. They wanted me to study regularly so I wouldn't regret it in the future."

P.24 "My family's attitudes and behaviors were positive in this period."

P.25 "My family has always been my supporter. When I was depressed, they tried to raise my morale. They made me think that I could get a good score from KPSS as I was able to accomplish most things so far."

P.29 "My family has always supported me."

Candidate teachers participating in the study stated that their families were oppressive, nervous and anxious under the name of negative opinion code. Some direct quotes regarding negative views are as follows:

P.1 "The attitude of my family during the pandemic period was more oppressive than usual, they thought that I should study more and be appointed because of staying at home." 
P.23 'Since everyone's mental state was very bad during the pandemic, the family members' attitudes towards me were also negative. On the one hand, they wanted me to study, on the other hand, they destroyed my motivation, which I hardly created by saying "You are working for nothing, maybe there will be no exams."

P.27 "My family was very tense during the pandemic period. So they made me worry more than motivated me."

Some direct quotations regarding candidate teachers' opinion that there has been no change participating in the study are as follows:

P.26 "It was normal. There was no change in family attitude."

P.32 "As I had a working family during the pandemic period, my responsibilities increased with the care of my nephews who had to stay at home. Apart from these expectations, my family kept its usual attitude."

Table 4. Findings regarding the opinions of social studies teacher candidates participating in the research on the advantages of preparing for KPSS during the pandemic period

\begin{tabular}{llc}
\hline Cods & Participants & $\mathrm{f}$ \\
\hline Study more for KPSS (lesson) & $2,3,4,6,7,8,9,10,12,15,16,18,20,21,22,23,24,25,28,31,32,33,34$ & 23 \\
Prevent waste of time & $1,5,29$ & 3 \\
Didn't have the advantage & $11,13,14,17,19,26,27,30$ & 8 \\
\hline
\end{tabular}

To the question "What are the advantages of preparing for KPSS during the pandemic period?", candidate teachers participated in the study stated 3 different views: studying more lessons (KPSS) $(\mathrm{f}=23)$, avoiding time loss ( $\mathrm{f}=3$ ) and no advantage $(\mathrm{f}=8)$.

Some direct quotations about teacher candidates' opinion of studying more (for KPSS) to are as follows:

P.4 "If I would mention the advantages of preparing for KPSS during the pandemic period, I had more time to study because the exam time was extended."

P. 7 "Since we stayed at home all the time during the pandemic period, it was a great advantage to have more time to study."

P.8 "Since I was always at home during the pandemic period, I had a lot of time for my lessons. I had a lot of free time and it was a great advantage for me."

P.9 "During the pandemic period, I stayed at home because the places where I spent time were closed. Thus I had the opportunity to concentrate more on my lesson. With the postponement of the exam date, I finished my missing subjects. I repeated the issues I forgot and felt incomplete."

P.10 "I had to spend more time at home due to the curfew during the pandemic period. That situation enabled me to spend more time for studying. In addition, with the postponement of the KPSS date, I had completed my missing issues."

P.16 "The fact that social life was interrupted during the pandemic period made me focus more on studying."

P.28 "The process of preparing for KPSS during the pandemic period was a positive factor for me. It involved me in studying only for exam away from external factors. That's why the period has been positive for me to study for the exam."

P.32 "With the prohibitions the time I spent studying increased. I think that was the only advantage."

Some direct quotations to the views of candidate teachers participating in the study on preventing time loss are as follows:

P.1 "The advantage of preparing for KPSS during the pandemic period, wasting time such as going and returning from the private teaching institution was prevented."

P.5 "It was very efficient in managing time as being at home all the time gave extra time. Moving away from the social environment contributed positively to my study."

Some direct quotations regarding the view "there is no any advantage" that the teacher candidates participating in the study are as follows:

P.11 "I do not think that the pandemic period creates an advantageous situation for the preparation for KPSS."

P.13 "Preparing for KPSS during the pandemic period did not have an advantage for me, but it has been an 
advantage for any person working in this period. Because they were able to study more."

P.17 "I did not see any advantage of the pandemic."

P.19 "I think there is no advantage in preparing for KPSS during the pandemic period. Because how much can you get in the mood for the student in the home environment? How much can we really isolate ourselves from everyone? We have to interact with each other. Guests always come to the home and as the only daughter of the house, all the housework is left to me. What shall we do, chase the guest? As you see, it is difficult to be a Female in these days."

Table 5. Findings regarding the opinions of social studies teacher candidates participating in the research on the disadvantages of preparing for KPSS during the pandemic period

\begin{tabular}{lll}
\hline Cods & Participants & $\mathrm{f}$ \\
\hline Inability to do activities-Not to socialize & $2,3,15,17,22,23,25,33$ & 8 \\
Anxiety-Stress & $7,8,11,20,27$ & 5 \\
Boredom-Reluctance & $24,28,30,31,34$ & 5 \\
Not being able to focus, Not able to motivated & $9,10,16,18$ & 4 \\
Unfavorable study environment & $14,19,21,26$ & 4 \\
Fear of getting sick & $1,4,13,32$ & 4 \\
It did not have any disadvantages & $5,6,12,29$ & 4 \\
\hline
\end{tabular}

To the question "What are the disadvantages of preparing for KPSS during the pandemic period?", the teacher candidates participating in the research mostly stated the view of not being able to do activity-not socialize $(\mathrm{f}=8)$. Secondly, anxiety-stress $(f=5)$ and boredom-reluctance $(f=5)$ responses emerged. The least stated answers were not being able to focus-not being motivated $(f=4)$, negative study environment $(f=4)$, fear of getting sick $(f=4)$, and no disadvantages $(\mathrm{f}=4)$.

Some direct quotations about the views of the teacher candidates participating in the study about not being able to do activities and not socialize are as follows:

P.2 "During this period, after studying lesson, I sometimes wanted to do different activities, but I could not do these activities because there was a curfew."

P.3 "As I could not relax my mind by doing any activity, I sometimes had a hard time concentrating on studying."

P.15 "Disadvantages: Restriction of social life has advantages as well as disadvantages. Because we need to clear our minds outside. We could not get face-to-face training, both KPSS and the pandemic were a difficult period."

P.33 "I had great difficulty in resting my head as I constantly spent time in my study environment. That was also a disadvantage for me."

Some direct quotations regarding the anxiety-stress views of the teacher candidates participating in the study are as follows:

P.7 "Studying during the pandemic, being psychologically stressed and thinking that everybody studied more than me increased my stress. This was the biggest disadvantage for me."

P.11 "As the exam was postponed to a later date due to the pandemic, my exam anxiety increased. Because the private teaching institutions were temporarily closed, the classes were given remotely and that were not as productive as face-to-face training."

P.27 "While experiencing a lot of anxiety about the future during the pandemic, it was a disadvantage in itself that exam anxiety was loaded on it due to KPSS."

Some direct quotations about the boredom-reluctance views of the teacher candidates participating in the study are as follows:

P.28 "The disadvantage of studying for the exam during the pandemic period was boredom and unwillingness after a certain period of time."

P.30 "Always studying lesson at home bores people."

P.31 "During the pandemic period, most of our time was spent at home, so I was reluctant to study."

Some direct quotations regarding the views of not being able to focus-not being motivated by the teacher 
candidates participating in the study are as follows:

P.9 "I was a student who prepared for exams in the library to be motivated. The pandemic forced me to study lesson by living in the same room all the time. This made it difficult for me to focus on KPSS."

P.18 "As I generally was at home, I had difficulty in concentrating on study."

Some direct quotations regarding the negative views of the teacher candidates participating in the study are as follows:

P.14 "The fact that all family members are at home caused too much noise. I could not find a quiet environment to study lesson in."

P.26 "Normally, I used to go to the private teaching institution and we were training face to face. Our online lessons started with the pandemic. But, our communication with the teachers during online lessons was very disordered. We couldn't even ask questions to the teachers. So we did not have a healthy working environment."

Some direct quotations regarding the view of the pre-service teachers who participated in the study on the fear of getting sick are as follows:

P.1 "Most students thought that the virus would infect them due to the pandemic. That's why I think it is not efficient to study lesson with this fear."

P.32 "The fear of living with a health worker family and getting sick affected my psychology very badly."

Some direct quotations regarding the view that teacher candidates participating in the study had no disadvantages are as follows:

P.5 "It did not effected me negatively. Because I was not going to institutions such as a the private teaching institution or study center. Therefore, I continued studying lesson in the same way."

P.12 "It didn’t effected me negatively, I was studying lesson at home anyway."

Table 6. Findings regarding the opinions of the social studies teacher candidates participating in the study comparing the preparation to KPSS during the pandemic period and the preparation to KPSS in the normal process

\begin{tabular}{llc}
\hline Cods & Participants & $\mathrm{f}$ \\
\hline More inefficient & $9,10,11,13,14,15,16,17,18,19,21,22,23,24,25,26,27,30,32$, & 19 \\
More efficient & $1,2,5,8,20,28,29,31,33,34$ & 10 \\
There is no difference & $3,4,6,7,12$ & 5 \\
\hline
\end{tabular}

"Could you compare your preparation for KPSS during the pandemic period and your preparation for KPSS in the normal period?" to the question, the preservice teachers who participated in the study expressed 3 different opinions as less efficient $(f=19)$, more efficient $(f=10)$ and no difference $(f=5)$.

Some direct quotes about the less efficient views of the teacher candidates participating in the study are as follows:

P.9 "I used to walk to breathe in the evenings after studying when there was no pandemic. In the evening I would go to bed with my head empty, rested and in peace. But during the pandemic period, I could not go out and it made me stressed more, even for breathing. That's why I woke up to a more stressful and anxious day every day."

P.10 "When there was no pandemic, I had more desire to study lesson. With the candidates preparing for the KPSS exam, we were helping each other about lessons and motivating each other. I was learning about topics and information that I didn't know. During the pandemic period, my motivation decreased because I was at home all the time."

P.11 "I made a lesson plan according to myself in the normal period. However, with the mental breakdown I experienced during the pandemic period, I was disconnected from the order I created day by day."

P.14 "Normally, the house was quiet and I could study comfortably. However, when all family members were at home due to the pandemic, I could not find a quiet place to study. Also, the fear of getting sick due to the pandemic increased my anxiety level. That's why I couldn't focus on my lessons."

P.23 "In the normal period of time, my only concern was whether I will be successful in the exam or not, but during the pandemic even I hesitated to take the exam like most individuals. The fear of death that occurred during the pandemic had a negative effect on my working pace."

P.25 "Preparing for KPSS during the pandemic was a very difficult and tiring period. With the postponement of 
KPSS, I started to get bored. It was much better to prepare for KPSS in normal period. Because we could go to the library and the private teaching institution whenever we wanted, and we could study in different environments. But during the pandemic period, I always had to study at home. Since it is not known whether KPSS will be done or not due to the pandemic, we remained in an uncertainty. But in the normal period, we were planning ourselves accordingly, since the time of everything was certain. In addition, the pandemic affected our psychology very badly."

P.27 "My time management was very bad during the pandemic period. My sleep disorders and nutritional changes affected negatively my study for KPSS. I had a more successful study period before the pandemic."

Some direct quotations regarding the more efficient views of teacher candidates participating in the study are as follows:

P.1 "Preparing for KPSS during the pandemic period was more efficient for me. Because I worked more efficiently and programmatically. In addition, I completed my missing subjects after the exam had been postponed to a later date."

P.2 "Under normal circumstances, I did not have much time to study KPSS. However, I had the opportunity to study more during the pandemic period."

P.8 "Since I was always at home during the pandemic period, my study for KPSS had been more efficient. I spent more time to KPSS."

Some direct quotations regarding the opinions of candidate teachers participating in the study that there is no difference are as follows:

P.7 "I cannot say that there is much difference for me between preparing for KPSS during the pandemic period and preparing for the normal period. If I think I understand better in which time period, I worked in that time period. This situation was the same in the normal period and the same during the pandemic period."

P.12 "Both were the same, there was not much change for me."

\section{Discussion, Conclusion and Suggestions}

When we look at the works about the pandemic, it is seen that almost all of them are in the field of health. However, in recent years, it has been observed that it has been presented in many areas such as sociology, economy, business, education in addition to the field of health.

C1kman (2011) aimed to examine pandemic influenza A (H1N1) cases detected in his region in his medical specialty thesis titled "Examination of pandemic influenza A (H1N1) cases in our region". He stated that pandemic influenza A (H1N1) infection is more common in patients and young people who do not have risk factors, in contrast to seasonal flu. In general, pandemic influenza has mild symptoms as in seasonal flu, but it causes more serious clinical situations and even deaths in people with different diseases.

Tiftikci (2020) aimed to investigate the effect of the COVID-19 pandemic on the education of emergency medical assistants in her master's thesis titled "The effect of the COVID-19 pandemic period over the education of emergency medical assistants and job tension". At the end of her research, Tiftikci stated that emergency services are inherently stressful environments, and that stress situations increase more with the increase of tension arising from contagious diseases, feeling lonely during working hours, and disruption of education. She emphasized that the use of factors such as improving personal protective equipment and including internet-based alternative education resources in education may be effective in reducing the stress in the COVID-19 pandemic period.

Karaday1 (2020) aimed to investigate the effect of COVID-19 pandemic on the burnout levels of anesthesiology and reanimation specialists and research assistants in his medical specialty thesis titled "The effect of COVID-19 pandemic on burnout in anesthesiology and reanimation specialists and research assistants". At the end of the study, it was emphasized that nearly half of the healthcare professionals participating in the study had high levels of burnout, and that burnout negatively affected not only themselves but also their families, friends and patients. It has been stated that situation increases the probability of making mistakes by healthcare professionals and so the possibility of being hurt increases for patients.

Aksoy (2020) has analyzed how the COVID-19 pandemic affects the purchasing behavior of consumers in his master's thesis titled "Consumer behavior in the economic crisis: a qualitative research in the COVID-19 pandemic". At the end of the study, it was revealed that consumers were adversely affected by the crisis and they preferred discounted and cheap products by acting more carefully about spending their money.

Kurnaz and Sercemeli (2020) wrote an article titled "A research on the perspectives of academics towards distance 
education and distance accounting education during the COVID-19 pandemic period". Kurnaz and Sercemeli aimed to determine the views of academicians who take classes in accounting during the COVID-19 pandemic on distance education. Kurnaz and Sercemeli emphasized that at the end of their research, the academicians participating in the research could not adopt the distance education system. In addition, among the reasons for the negative factors of distance education in accounting courses, the lack of mutual interaction between students and academicians attending the courses and the inability to present theory and practice together in the courses were listed.

Kocoglu et al. (2020), in their article "An overview of Education in Turkey during the COVID-19 pandemic", aimed to evaluate the educational systems carried out in Turkey during the COVID-19 pandemic. At the end of the study, it was concluded that there are regional differences due to reasons such as distance education, vision in education, infrastructure in technology and economic differences. In addition, it was emphasized that the training provided at every education level should be based on some elements.

Based on the findings of this study, which aims to reveal the opinions of the teacher candidates who graduated from the department of social studies teaching on the effects of the pandemic process on the preparations for KPSS, the following results have been reached:

- During the pandemic period, the most preferred sources by teacher candidates who are preparing for KPSS are; videos, books, online lectures, articles and lecture notes.

- Most of the pre-service teachers who were preparing for KPSS during the pandemic period stated that their families' attitudes towards them were generally positive during this period. Some of the pre-service teachers who participated in the study stated that their families 'attitudes towards themselves were negative in this period, and other teacher candidates stated that there was no change in their families' attitudes towards them.

- Most of the pre-service teachers participating in the research, in their opinions regarding the advantages of preparing for KPSS during the pandemic process; They stated that they were working more for KPSS during the pandemic process and the loss of time was prevented. Other teacher candidates who participated in the study emphasized that there is no difference while preparing for KPSS during the pandemic process.

- In the opinions of the teacher candidates participating in the study regarding the disadvantages of preparing for KPSS during the pandemic period, the following views have emerged, respectively: Inability to do activities-not socialize, anxiety-stress, boredom-reluctance, not being able to focus-not being motivated, negative study environment and fear of getting sick. Some teacher candidates who participated in the study stated that the pandemic period did not have any disadvantages for them in preparing for KPSS.

- When the teacher candidates participating in the study compared the preparation for KPSS during the pandemic period and the preparation for the KPSS in the normal period, more than half of the pre-service teachers stated that the pandemic period affected negatively their KPSS studies. While some of the pre-service teachers emphasized that preparing for KPSS during the pandemic period is more efficient, other pre-service teachers stated that there is no difference between preparing for KPSS during the pandemic period and preparing for KPSS in the normal period.

Based on the findings and results, the following suggestions have been made:

- Necessary trainings can be given to families if needed in order to overcome the pandemic period in a healthy way.

- In case of need, trainings can be given to teacher candidates who are prepared for KPSS to overcome the pandemic period in a healthy way.

- Various educational seminars can be organized both on social media and on televisions to increase the motivation of teacher candidates who are preparing for KPSS.

- In order to provide equal education opportunities to students preparing for exams like KPSS, YKS, YDS, YKS etc. , free online education can be provided by the government.

- Within the scope of distance education, necessary training can be given to students in the use of information technologies.

\section{References}

Aksoy, C. (2020). Consumer behavior in the economic downturn: A qualitative research during COVID-19 pandemic (Master thesis, Bahcesehir University Institute of Social Sciences Department of Business Administration, İstanbul). 
Arslan, I., \& Karagul, S. (2020). A Global Threat (COVID-19 Pandemic) and the Journey to Change. Uskudar University Journal of Social Sciences, 10, 1-36. https://doi.org/10.32739/uskudarsbd.6.10.67

Baltaci, A. (2018). A conceptual review of sampling methods and sample size problems in qualitative research. Journal of Bitlis Eren University Institute of Social Sciences, 7(1), 231-274.

Buyukozturk, S., K1lıc Cakmak, E., Akgun, O. E., Karadeniz, S., \& Demirel, F. (2008). Scientific research methods. Ankara: Pegem Publications.

Carrasco-Hernandez, R., Jacome, R., Vidal, L., \& Leon, P. (2017). Are RNA Viruses Candidate Agents for the Next Global Pandemic? A Review. ILAR Journal, 58(3), 343-358. https://doi.org/10.1093/ilar/ilx026

C1kman, A. (2011). Discussion of pandemic influenza A (H1N1) cases in our region (Expertise Thesis, Yuzuncu Y1l University Faculty of Medicine Department of Medical Microbiology, Van).

Karaday1, B. S. (2020). Effect of COVID-19 Pandemic on Burnout in Anesthesiology and Reanimation Specialist and Residents (Expertise Thesis, Cukurova University Faculty of Medicine Department of Anesthesiology and Reanimation, Adana).

Karatas, Z. (2020). Social Impacts of COVID-19 Pandemic, Change and Empowerment. Turkey Journal of Social Service Research, 4(1), 3-15.

Kocoglu, E., Ulu Kalın, O., Tekdal, D., \& Yigen, V. (2020). Covid-19 Pandemic Process, Education at a Glance in Turkey. Social Sciences Studies Journal, 6(65), 2956-2966. https://doi.org/10.26449/sssj.2448

Kurnaz, E., \& Sercemeli, M. (2020). A. Research on Academicans' Perspectives on Distance Education and Distance Accounting Education in the COVID-19 Pandemia Period. International Journal of Social Sciences Academy, 2(3), 262-288.

Miles, M. B., \& Huberman, A. M. (1994). Qualitative data analysis: An expanded sourcebook. Thousand Oaks, CA: Sage Publication.

Ornek Buken, N. (2020). COVID 19 Pandemic and Ethical Issues. Health and Society Magazine, Special Issue, 15-26.

Ozlu, A. \& Oztas, D. (2020). Learning Lessons from the Past in Combating the Novel Coronavirus (COVID-19) Pandemic. Ankara Medical Journal, 2, 468-481. https://doi.org/10.5505/amj.2020.46547

Tedmem, Z. S., Palancı, M., Kandemir M., \& Dundar, H. (2014). Tendencies of the Researches Published in Education and Science Journal: Content Analysis. Education and Science, 173(39), 430-453.

Tezekici, M. C. (2020). Global Outbreak Threat and Security, Found Work: The Effects of the Pandemic Global Crisis on Education (Ed., Tansu, Y. E.), Gaziantep: IKSAD.

Tiftikci, I. (2020). Effect of COVID-19 pandemic on emergency medicine specialty training and work-related strain (Master thesis, Akdeniz University, Institute of Health Sciences, Department of Medical Education, Antalya).

Timmins, F., \& McCabe, C. (2005). How to conduct an effective literature search. Art \& Science Study Skills, 11(20), 41-47. https://doi.org/10.7748/ns2005.11.20.11.41.c4010

TUBA. (2020). COVID-19 Pandemic Assessment Report (Ed. Sugar, M. et al.). Academy of Sciences of Turkey, Ankara.

Yıldırım, A., \& Simsek H. (2008). Qualitative research methods in the social sciences. Ankara: Seckin Publishing.

\section{Copyrights}

Copyright for this article is retained by the author(s), with first publication rights granted to the journal.

This is an open-access article distributed under the terms and conditions of the Creative Commons Attribution license (http://creativecommons.org/licenses/by/4.0/). 